\title{
The Toxicity of Wiped Dust and Airborne Microbes in Individual Classrooms Increase the Risk of Teachers' Work-Related Symptoms: A Cross-Sectional Study
}

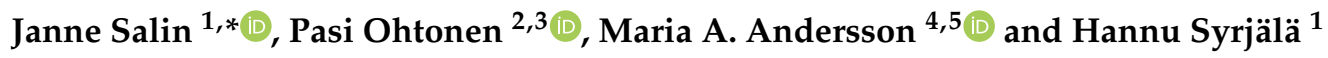 \\ 1 The Department of Infection Control, Oulu University Hospital, FI-90029 Oulu, Finland; \\ hannu.syrjala@ppshp.fi \\ 2 Division of Operative Care, Oulu University Hospital, FI-90220 Oulu, Finland; pasi.ohtonen@oulu.fi \\ 3 Research Unit of Surgery, Anesthesia and Intensive Care, University of Oulu, FI-90014 Oulu, Finland \\ 4 Department of Microbiology, Faculty of Agriculture and Forestry, University of Helsinki, FI-00014 Helsinki, \\ Finland; maria.a.andersson@helsinki.fi \\ 5 Department of Civil Engineering, Aalto University, FI-00076 Aalto, Finland \\ * Correspondence: janne.salin@oulu.fi; Fax: +358-8-315-2452
}

check for

updates

Citation: Salin, J.; Ohtonen, P.; Andersson, M.A.; Syrjälä, H. The Toxicity of Wiped Dust and Airborne Microbes in Individual Classrooms Increase the Risk of Teachers' Work-Related Symptoms: A Cross-Sectional Study. Pathogens 2021, 10, 1360. https://doi.org/10.3390/ pathogens10111360

Academic Editor: Donát Magyar

Received: 20 August 2021

Accepted: 12 October 2021

Published: 21 October 2021

Publisher's Note: MDPI stays neutral with regard to jurisdictional claims in published maps and institutional affiliations.

Copyright: (c) 2021 by the authors. Licensee MDPI, Basel, Switzerland. This article is an open access article distributed under the terms and conditions of the Creative Commons Attribution (CC BY) license (https:// creativecommons.org/licenses/by/ $4.0 /)$.

\begin{abstract}
Background: The causes and pathophysiological mechanisms of building-related symptoms (BRS) remain open. Objective: We aimed to investigate the association between teachers' individual work-related symptoms and intrinsic in vitro toxicity in classrooms. This is a further analysis of a previously published dataset. Methods: Teachers from 15 Finnish schools in Helsinki responded to the symptom survey. The boar sperm motility inhibition assay, a sensitive indicator of mitochondrial dysfunction, was used to measure the toxicity of wiped dust and cultured microbial fallout samples collected from the teachers' classrooms. Results: 231 teachers whose classroom toxicity data had been collected responded to the questionnaire. Logistic regression analysis adjusted for age, gender, smoking, and atopy showed that classroom dust intrinsic toxicity was statistically significantly associated with the following 12 symptoms reported by teachers (adjusted ORs in parentheses): nose stuffiness (4.1), runny nose (6.9), hoarseness (6.4), globus sensation (9.0), throat mucus (7.6), throat itching (4.4), shortness of breath (12.2), dry cough (4.7), wet eyes (12.7), hypersensitivity to sound (7.9), difficulty falling asleep (7.6), and increased need for sleep (7.7). Toxicity of cultured microbes was found to be associated with nine symptoms (adjusted ORs in parentheses): headache (2.3), nose stuffiness (2.2), nose dryness (2.2), mouth dryness (2.8), hoarseness (2.2), sore throat (2.8), throat mucus (2.3), eye discharge (10.2), and increased need for sleep (3.5). Conclusions: The toxicity of classroom dust and airborne microbes in boar sperm motility inhibition assay significantly increased teachers' risk of work-related respiratory and ocular symptoms. Potential pathophysiological mechanisms of BRS are discussed.
\end{abstract}

Keywords: building-related symptoms; indoor toxicity; boar sperm motility inhibition assay; mitochondrial toxicity; mitochondrial dysfunction

\section{Introduction}

Building-related symptoms (BRS) have been reported worldwide for decades [1]. Classic BRS include eye, nose, respiratory, and skin symptoms, as well as headache, fatigue, dizziness, inability to concentrate, nausea, fever, and chills [2,3]. In addition, exposure to moisture damage in buildings and emissions from indoor mold growth have been shown to be associated with the development and exacerbation of asthma, allergic rhinitis, and bronchitis [4-6]. However, the pathophysiological mechanisms and causal relationships of symptoms remain unclear.

In moisture-damaged buildings, a variety of toxic fungi and bacteria are known to grow in the structures, ventilation systems and on indoor surfaces [7-12]. Airborne dust, 
spores, and hyphae fragments can act as carriers of microbial toxins in indoor air [13-15]. Recent studies show that toxins can also be very easily aerosolized [16,17], particularly even without airflow, due to highly toxic guttation droplets secreted by microbes actively growing on building materials [10,11,18-20]. Settled dust collected from moisture-damaged buildings has been found to contain microbial toxins [21-28].

In toxicity measurements, various dust sampling and processing methods and different in vitro models have demonstrated contradictory results [16,29-32]. The inflammatory potential of the deposited dust in human lung epithelial cell A549 assay was statistically significantly associated with employees' symptoms in schools [33] and offices [29]. A1though the immunotoxicity of indoor samples in the mouse RAW264.7 macrophage assay has been described to reduce after the renovation of moisture-damaged schools [31,34], it was not possible to distinguish moisture-damaged schools from control schools with this method [32,35]. The same holds true for hemolytic activity tested on human erythrocytes or oxidative capacity by plasmid scission assay [36].

The classic boar sperm motility inhibition (BSMI) assay has been found to be a sensitive method for detecting bacterial and mycotoxins in moisture-damaged buildings [9,11,16,37-46]. The method has also shown to be sensitive to man-made xenobiotic mitochondriotoxic chemicals known to occur in indoor dusts [47,48]. In a recent study, a clear temporal association was found between heavy occupational exposure to sperm-toxic dust during renovation of a water-damaged building and a cluster of 21 new occupational asthma cases [49].

We previously showed that both the total number of literature-known BRS [50] and the most common other work-related symptoms [51] were associated with intrinsic in vitro toxicity of settled dust and cultivated airborne microbes from teachers' classrooms. The aim of this sub-analysis of the same dataset was to investigate whether there is an association between teachers' individual symptoms and the toxicity of dust and airborne microbes

\section{Results}

Two hundred and thirty-one teachers met the admission criteria, and had completed a questionnaire, and had at least one classroom toxicity result (200 respondents had microbial toxicity results and 169 respondents had dust toxicity results) [50,51]. The median age of the respondents was 43 years, $81.8 \%$ were women, $9.5 \%$ were current smokers, and $10.4 \%$ were atopic. Their median working time at their primary workplace was $22 \mathrm{~h}$ per week.

Table 1 shows the prevalence and association with the workplace of the literatureknown BRS and the most common other symptoms (prevalence over 10\%), of which at least $50 \%$ were perceived to be work-related. There was a total of 41 such symptoms, including 7 general, 17 respiratory, 3 dermal, 6 ocular, 2 hearing, 3 sleeping, and 3 mental symptoms. The highest work-relatedness (at least $70 \%$ of the symptom worsening in the workplace) was reported for eight symptoms: three general symptoms (fatigue, generalized feeling of sickness, indefinite feeling of thermoregulation failure), four respiratory symptoms (hoarseness, dry cough, throat mucus, throat itching), and one mental symptom (mental irritability). 
Table 1. Number of total and work-related symptoms in 231 teachers.

\begin{tabular}{|c|c|c|c|}
\hline & $\begin{array}{l}\text { Total, } \\
N(\%)\end{array}$ & $\begin{array}{l}\text { Work-Related, } \\
\quad N(\%)\end{array}$ & $\begin{array}{c}\text { Literature-Known BRS, } \\
\text { Yes or No }\end{array}$ \\
\hline \multicolumn{4}{|l|}{ GENERAL SYMPTOMS } \\
\hline Fatigue & $88(38.1)$ & $65(28.1)$ & yes \\
\hline Headache & $92(39.8)$ & $46(20.0)$ & yes \\
\hline Fever & $13(5.6)$ & $8(3.5)$ & yes \\
\hline Chills & 31 (13.4) & $19(8.2)$ & yes \\
\hline Generalized feeling of sickness & $60(26.0)$ & $46(20.0)$ & no \\
\hline Decreased physical condition & $54(23.4)$ & $27(11.7)$ & no \\
\hline $\begin{array}{l}\text { Indefinite feeling of } \\
\text { thermoregulation failure } \\
\text { RESPIRATORY SYMPTOMS }\end{array}$ & 27 (11.7) & $19(8.2)$ & no \\
\hline Nose stuffiness & $106(45.9)$ & $64(27.7)$ & yes \\
\hline Nose dryness & $84(36.4)$ & $52(22.5)$ & yes \\
\hline Nose stinging & $22(9.5)$ & $7(3.0)$ & yes \\
\hline Bloody nasal discharge & $30(13.0)$ & $16(6.9)$ & yes \\
\hline Runny nose & $74(32.0)$ & $37(16.0)$ & yes \\
\hline Sneezing & $66(28.6)$ & 39 (16.9) & yes \\
\hline Mouth dryness & $48(20.8)$ & $30(13.0)$ & yes \\
\hline Hoarseness & $88(38.1)$ & $62(26.8)$ & yes \\
\hline Sore throat & $42(18.2)$ & $27(11.7)$ & yes \\
\hline Wheezing & $15(6.5)$ & $4(1.7)$ & yes \\
\hline Shortness of breath & $21(9.1)$ & $12(5.2)$ & yes \\
\hline Asthma attacks & $12(5.2)$ & $5(2.2)$ & yes \\
\hline Dry cough & $53(22.9)$ & 40 (17.3) & yes \\
\hline Pressure in the cheek & $42(18.2)$ & $22(9.5)$ & no \\
\hline Globus sensation & 31 (13.4) & $19(8.2)$ & no \\
\hline Throat mucus & $70(30.3)$ & $50(21.6)$ & no \\
\hline $\begin{array}{l}\text { Throat itching } \\
\text { DERMAL SYMPTOMS }\end{array}$ & \multicolumn{2}{|c|}{ DERMAL SYMPTOMS } & no \\
\hline Skin dryness & $58(25.1)$ & $20(8.7)$ & yes \\
\hline Exanthema & $13(5.6)$ & $3(1.3)$ & yes \\
\hline $\begin{array}{l}\text { Pruritus } \\
\text { EYE SYMPTOMS }\end{array}$ & \multicolumn{2}{|c|}{ EYE SYMPTOMS } & yes \\
\hline Eye irritation & $61(26.4)$ & $39(16.9)$ & yes \\
\hline Wet eyes & $30(13.0)$ & $15(6.5)$ & yes \\
\hline Dry eyes & $67(29.0)$ & 45 (19.5) & yes \\
\hline Swollen eyelids & $19(8.2)$ & $9(3.9)$ & yes \\
\hline Red eyes & $32(13.9)$ & $18(7.8)$ & no \\
\hline $\begin{array}{l}\text { Eye discharge } \\
\text { HEARING SYMPTOMS }\end{array}$ & $24(10.4)$ & $14(6.1)$ & no \\
\hline $\begin{array}{l}\text { Difficulty distinguishing speech } \\
\text { in noise }\end{array}$ & $51(22.1)$ & $27(11.7)$ & no \\
\hline $\begin{array}{l}\text { Hypersensitivity to sound } \\
\text { SLEEPING SYMPTOMS }\end{array}$ & $28(12.1)$ & $14(6.1)$ & no \\
\hline Insomnia & $41(17.7)$ & $25(10.8)$ & yes \\
\hline Difficulty falling asleep & $42(18.2)$ & $21(9.1)$ & yes \\
\hline $\begin{array}{l}\text { Increased need for sleep } \\
\text { MENTAL SYMPTOMS }\end{array}$ & $34(14.7)$ & $18(7.8)$ & no \\
\hline Difficulty concentrating & $12(5.2)$ & $4(1.7)$ & yes \\
\hline Mental irritability & 29 (12.6) & $22(9.5)$ & no \\
\hline $\begin{array}{c}\text { Decreased stress resistance } \\
\text { BUILDING-RELATED } \\
\text { DISEASES }\end{array}$ & $26(11.3)$ & $18(7.8)$ & no \\
\hline Asthma & $22(9.5)$ & $a$ & yes \\
\hline Allergic rhinitis & $32(13.9)$ & $a$ & yes \\
\hline
\end{tabular}

Modified from [51]. ${ }^{a}$ A disease diagnosed by a physician, association with work was not studied. BRS, buildingrelated symptoms.

Dust toxicity was divided into three categories and microbial toxicity into two categories $[50,51]$. The number of teachers with primary workspace dust toxicity results was $169 ; 111(65.7 \%)$ were non-toxic $\left(\mathrm{EC}_{50} \geq 25 \mu \mathrm{g} / \mathrm{mL}\right), 43(25.4 \%)$ were low toxic $\left(\mathrm{EC}_{50}=12 \mu \mathrm{g} / \mathrm{mL}\right)$ and $15(8.9 \%)$ were highly toxic $\left(\mathrm{EC}_{50} \leq 6 \mu \mathrm{g} / \mathrm{mL}\right)$. The number of teachers with primary workspace microbial toxicity results was 200; $118(59 \%)$ were non-toxic $\left(E_{50}>12 \mu \mathrm{g} / \mathrm{mL}\right)$, and $82(41 \%)$ were toxic $\left(E_{50} \leq 12 \mu \mathrm{g} / \mathrm{mL}\right)$. The fallout plates representative for sampling are pictured in Figure 1. The mold genera recognized based on colony morphology on MEA plates were Penicillium, Aspergillus, and Trichoderma. 
The dominant genera, representing Trichoderma isolates, were detected on $19 \%$ of the plates. The isolates were covering and feeding on co-growing fungal colonies, and apparently represent mycoparasitic species. The mycoparasitic and mycotrophic Trichoderma isolates covered between $5 \%$ and $>50 \%$ of all plates collected in the different schools. Trichoderma isolates grew in $13(15.9 \%)$ toxic fallout plates and two $(1.7 \%)$ non-toxic plates $(p<0.001$, Fisher's exact test).

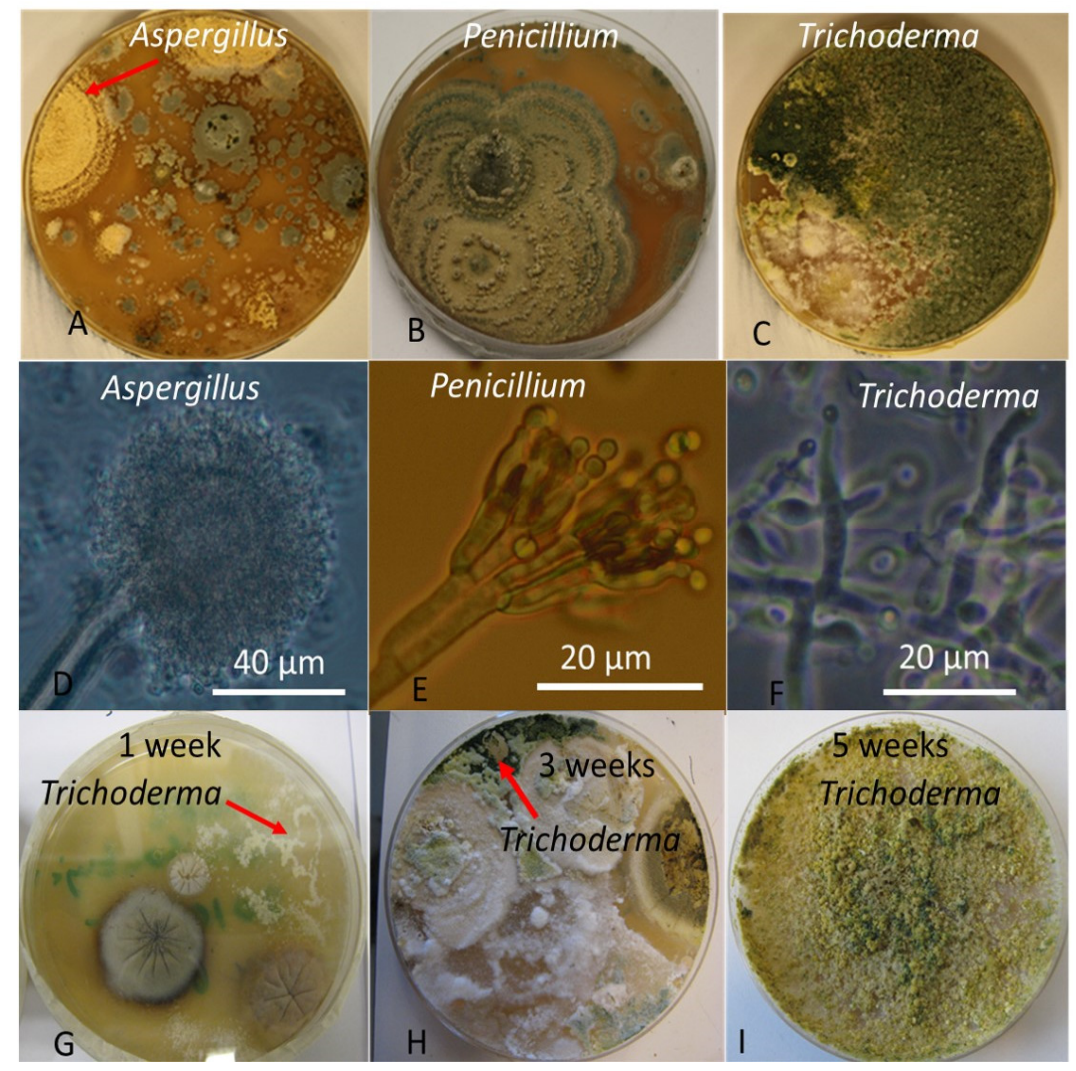

Figure 1. Diversity of the major toxigenic fungal genera obtained on fallout plates from the 15 schools. Panels (A) (arrow), (B,C) in the upper row show the dominant colony types on malt extract agar incubated for 4-6 weeks at $21^{\circ} \mathrm{C}$. The middle row: Panels (D-F) show the conidia of the colonies pictured using a phase contrast microscope. The lower row shows the mycoparasitic growth characteristic for representatives of the genus Trichoderma. Panel (G) shows lately germinated young hyphae (arrow) after 1 week of incubation. Panel (H) shows hyphae covering cogrowing fungi producing new green conidia (arrow). Panel (I) shows a 5-week-old plate completely covered by green conidia of Trichoderma. Representatives of mycoparasitic members of the genus Trichoderma covered 19\% of the plates collected, and represented the dominant characteristic fungal genus.

According to the logistic regression model based on dust samples and adjusted for age, gender, smoking, and atopy (Table 2), 12 work-related symptoms were statistically significantly more common among teachers whose primary classroom was highly toxic compared to non-toxic classrooms (adjusted ORs in parentheses): nose stuffiness (4.1), runny nose (6.9), hoarseness (6.4), globus sensation (9.0), throat mucus (7.6), throat itching (4.4), shortness of breath (12.2), dry cough (4.7), wet eyes (12.7), hypersensitivity to sound (7.9), difficulty falling asleep (7.6), and increased need for sleep (7.7). Based on analyses of cultured microbial fallout samples (Table 3) among teachers whose classrooms were toxic, nine work-related symptoms were statistically significantly more common compared to non-toxic classes (adjusted ORs in parentheses): headache (2.3), nose stuffiness (2.2), nose dryness (2.2), mouth dryness (2.8), hoarseness (2.2), sore throat (2.8), throat mucus (2.3), eye discharge (10.2), and increased need for sleep (3.5). ORs could not be calculated for three symptoms (nose stinging, wheezing, and exanthema) because these symptoms 
were not reported by teachers in the group of non-toxic microbes. Work-related nose stinging occurred in $4 / 82$ and $0 / 118$ teachers with and without toxic airborne microbes in their classrooms, respectively. The crude OR results are presented in the Supplementary Tables S1 and S2.

Table 2. Results of the multivariable adjusted logistic regression models for the impact of increased toxicity levels of wiped dust in the classroom on work-related symptoms.

\begin{tabular}{|c|c|c|c|c|}
\hline & $\mathrm{EC}_{50} 12 \mu \mathrm{g} \mathrm{mL}^{-1}$ & & $\begin{array}{c}\mathrm{EC}_{50} \leq 6 \mu \mathrm{g} \\
\mathrm{mL}^{-1}\end{array}$ & \\
\hline & OR (95\% CI) & $p$ Value & OR (95\% CI) & $p$ Value \\
\hline \multicolumn{5}{|l|}{ GENERAL SYMPTOMS } \\
\hline Fatigue & $1.08(0.46,2.53)$ & 0.86 & $3.00(0.96,9.36)$ & 0.058 \\
\hline Headache & $1.04(0.41,2.65)$ & $>0.90$ & $1.79(0.49,6.57)$ & 0.38 \\
\hline Fever & $3.75(0.63,22.2)$ & 0.15 & $2.59(0.23,29.4)$ & 0.44 \\
\hline Chills & $1.50(0.41,5.56)$ & 0.54 & $1.22(0.13,11.2)$ & 0.86 \\
\hline Generalized feeling of sickness & $1.11(0.42,2.94)$ & 0.84 & $3.28(1.00,10.8)$ & 0.050 \\
\hline Decreased physical condition & $1.08(0.31,3.72)$ & 0.90 & $3.85(0.99,15.0)$ & 0.052 \\
\hline \multicolumn{5}{|l|}{ RESPIRATORY SYMPTOMS } \\
\hline Nose stuffiness & $1.78(0.76,4.15)$ & 0.18 & $4.08(1.24,13.4)$ & 0.021 \\
\hline Nose dryness & $1.65(0.69,3.91)$ & 0.26 & $0.97(0.24,4.01)$ & $>0.90$ \\
\hline Nose stinging & $0.67(0.07,6.37)$ & 0.73 & $1.67(0.17,16.8)$ & 0.66 \\
\hline Bloody nasal discharge & $3.33(0.73,15.2)$ & 0.12 & $2.22(0.21,23.0)$ & 0.51 \\
\hline Runny nose & $4.24(1.49,12.1)$ & 0.0070 & $6.93(1.76,27.2)$ & 0.0056 \\
\hline Sneezing & $1.17(0.43,3.18)$ & 0.76 & $2.07(0.55,7.75)$ & 0.28 \\
\hline Mouth dryness & $1.99(0.63,6.33)$ & 0.24 & $2.29(0.49,10.5)$ & 0.29 \\
\hline Hoarseness & $3.38(1.47,7.75)$ & 0.0041 & $6.42(1.95,21.1)$ & 0.0022 \\
\hline Sore throat & $0.92(0.17,4.95)$ & $>0.90$ & $3.80(0.72,19.9)$ & 0.12 \\
\hline Wheezing & $4.43(0.21,95.2)$ & 0.34 & $7.56(0.27,209)$ & 0.23 \\
\hline Shortness of breath & $3.69(0.76,17.9)$ & 0.10 & $12.2(1.95,76.8)$ & 0.0076 \\
\hline Asthma attacks & $7.07(0.55,91.3)$ & 0.13 & $14.8(1.00,219)$ & 0.050 \\
\hline Dry cough & $2.14(0.81,5.70)$ & 0.13 & $4.65(1.29,16.8)$ & 0.019 \\
\hline Pressure in the cheek & $0.36(0.04,3.17)$ & 0.36 & $2.76(0.46,16.6)$ & 0.27 \\
\hline Globus sensation & $1.34(0.23,7.72)$ & 0.74 & $9.02(1.74,46.7)$ & 0.0088 \\
\hline Throat mucus & $2.46(0.99,6.14)$ & 0.053 & $7.64(2.21,26.4)$ & 0.0013 \\
\hline Throat itching & $2.19(0.71,6.75)$ & 0.17 & $4.35(1.08,17.6)$ & 0.039 \\
\hline \multicolumn{5}{|l|}{ DERMAL SYMPTOMS } \\
\hline Skin dryness & $0.66(0.17,2.50)$ & 0.54 & $0.65(0.07,5.55)$ & 0.69 \\
\hline Exanthema & $3.45(0.15,78.0)$ & 0.44 & $14.78(0.36,606)$ & 0.16 \\
\hline Pruritus & $0.63(0.06,6.29)$ & 0.69 & $2.24(0.19,26.2)$ & 0.52 \\
\hline \multicolumn{5}{|l|}{ EYE SYMPTOMS } \\
\hline Eye irritation & $0.93(0.30,2.90)$ & $>0.90$ & $3.58(0.89,14.4)$ & 0.072 \\
\hline Wet eyes & $4.06(0.65,25.3)$ & 0.13 & $12.7(1.44,112)$ & 0.022 \\
\hline Dry eyes & $0.86(0.31,2.40)$ & 0.78 & $1.94(0.52,7.28)$ & 0.32 \\
\hline Swollen eyelids & $0.65(0.07,6.28)$ & 0.71 & $2.29(0.21,25.5)$ & 0.50 \\
\hline Red eyes & $0.26(0.03,2.46)$ & 0.24 & $2.34(0.17,31.4)$ & 0.52 \\
\hline Eye discharge & $0.80(0.08,8.25)$ & 0.85 & $7.69(0.96,61.4)$ & 0.054 \\
\hline \multicolumn{5}{|l|}{ HEARING SYMPTOMS } \\
\hline Difficulty distinguishing speech in noise & $0.14(0.02,1.16)$ & 0.069 & $2.10(0.45,9.69)$ & 0.34 \\
\hline Hypersensitivity to sound & N.D. & & $7.91(1.70,36.8)$ & 0.0084 \\
\hline \multicolumn{5}{|l|}{ SLEEPING SYMPTOMS } \\
\hline Insomnia & $1.00(0.32,3.11)$ & $>0.90$ & $2.57(0.59,11.2)$ & 0.21 \\
\hline Difficulty falling asleep & $1.14(0.32,4.02)$ & 0.84 & $7.58(1.93,29.8)$ & 0.0038 \\
\hline Increased need for sleep & $0.22(0.03,1.76)$ & 0.15 & $7.74(2.09,28.6)$ & 0.0022 \\
\hline \multicolumn{5}{|l|}{ MENTAL SYMPTOMS } \\
\hline Difficulty concentrating & N.D. & & $17.8(0.64,496)$ & 0.090 \\
\hline Mental irritability & $0.91(0.27,3.10)$ & 0.88 & $2.53(0.58,11.0)$ & 0.22 \\
\hline Decreased stress resistance & $1.42(0.39,5.18)$ & 0.60 & $3.33(0.75,14.8)$ & 0.11 \\
\hline \multicolumn{5}{|l|}{ BUILDING-RELATED DISEASES } \\
\hline Asthma & $2.13(0.59,7.76)$ & 0.25 & $1.44(0.22,9.51)$ & 0.70 \\
\hline Allergic rhinitis & $1.07(0.33,3.44)$ & 0.90 & $4.64(1.08,20.0)$ & 0.039 \\
\hline
\end{tabular}

The results are presented as odds ratios (ORs) with 95\% confidence intervals (CIs). ORs are adjusted for age, gender, smoking, and atopy. $P$ values are for comparisons between teachers with toxic and non-toxic classroom samples. The half maximal effective concentration (EC ( $_{50}$ ) indicates the degree of toxicity (ie, the lower the $\mathrm{EC}_{50}$, the higher the toxicity). N.D., not definable. 
Table 3. Results of the multivariable adjusted logistic regression models for the impact of toxicity of airborne microbes in the classroom on work-related symptoms.

\begin{tabular}{|c|c|c|}
\hline & $\mathrm{EC}_{50} \leq 12 \mu \mathrm{g} \mathrm{mL}^{-}$ & \\
\hline & OR $(95 \%$ CI $)$ & $p$ Value \\
\hline \multicolumn{3}{|l|}{ GENERAL SYMPTOMS } \\
\hline Fatigue & $1.63(0.85,3.12)$ & 0.14 \\
\hline Headache & $2.26(1.06,4.79)$ & 0.034 \\
\hline Fever & $2.80(0.42,18.6)$ & 0.29 \\
\hline Chills & $0.94(0.31,2.85)$ & $>0.90$ \\
\hline Generalized feeling of sickness & $1.81(0.85,3.85)$ & 0.12 \\
\hline Decreased physical condition & $1.47(0.59,3.64)$ & 0.40 \\
\hline \multicolumn{2}{|l|}{ RESPIRATORY SYMPTOMS } & 0.20 \\
\hline Nose stuffiness & $2.19(1.10,4.38)$ & 0.026 \\
\hline Nose dryness & $2.17(1.05,4.52)$ & 0.038 \\
\hline Nose stinging ${ }^{a}$ & N.D. & \\
\hline Bloody nasal discharge & $2.34(0.68,8.04)$ & 0.18 \\
\hline Runny nose & $2.07(0.92,4.66)$ & 0.79 \\
\hline Sneezing & $1.50(0.67,3.39)$ & 0.33 \\
\hline Mouth dryness & $2.76(1.13,6.71)$ & 0.026 \\
\hline Hoarseness & $2.18(1.12,4.26)$ & 0.022 \\
\hline Sore throat & $2.81(1.08,7.31)$ & 0.034 \\
\hline Wheezing ${ }^{a}$ & N.D. & \\
\hline Shortness of breath & $4.79(0.89,25.7)$ & 0.067 \\
\hline Asthma attacks & $1.67(0.11,24.5)$ & 0.71 \\
\hline Dry cough & $1.10(0.50,2.44)$ & 0.81 \\
\hline Pressure in the cheek & $2.60(0.89,7.59)$ & 0.079 \\
\hline Globus sensation & $2.32(0.76,7.05)$ & 0.14 \\
\hline Throat mucus & $2.28(1.09,4.74)$ & 0.028 \\
\hline Throat itching & $2.22(0.93,5.31)$ & 0.073 \\
\hline \multicolumn{3}{|l|}{ DERMAL SYMPTOMS } \\
\hline Skin dryness & $3.02(0.97,9.44)$ & 0.057 \\
\hline Exanthema ${ }^{a}$ & N.D. & \\
\hline Pruritus & $0.90(0.22,3.76)$ & 0.89 \\
\hline \multicolumn{3}{|l|}{ EYE SYMPTOMS } \\
\hline Eye irritation & $2.07(0.94,4.56)$ & 0.073 \\
\hline Wet eyes & $2.97(0.90,9.76)$ & 0.073 \\
\hline Dry eyes & $1.73(0.84,3.57)$ & 0.14 \\
\hline Swollen eyelids & $2.23(0.49,10.1)$ & 0.30 \\
\hline Red eyes & $2.70(0.91,7.99)$ & 0.072 \\
\hline Eye discharge & $10.2(2.03,50.9)$ & 0.0048 \\
\hline \multicolumn{3}{|l|}{ HEARING SYMPTOMS } \\
\hline Difficulty distinguishing speech in noise & $1.52(0.64,3.65)$ & 0.34 \\
\hline Hypersensitivity to sound & $0.72(0.20,2.56)$ & 0.61 \\
\hline \multicolumn{3}{|l|}{ SLEEPING SYMPTOMS } \\
\hline Insomnia & $1.85(0.70,4.91)$ & 0.22 \\
\hline Difficulty falling asleep & $2.54(0.87,7.46)$ & 0.089 \\
\hline Increased need for sleep & $3.54(1.03,12.2)$ & 0.045 \\
\hline \multicolumn{3}{|l|}{ MENTAL SYMPTOMS } \\
\hline Difficulty concentrating & $1.68(0.19,14.6)$ & 0.64 \\
\hline Mental irritability & $1.10(0.37,3.26)$ & 0.87 \\
\hline Decreased stress resistance & $0.98(0.31,3.06)$ & $>0.90$ \\
\hline \multicolumn{3}{|l|}{ BUILDING-RELATED DISEASES } \\
\hline Asthma & $1.28(0.43,3.77)$ & 0.66 \\
\hline Allergic rhinitis & $1.59(0.63,4.03)$ & 0.33 \\
\hline
\end{tabular}

The results are presented as odds ratios (ORs) with $95 \%$ confidence intervals (CIs). ORs are adjusted for age, gender, smoking, and atopy. $P$ values are for comparisons between teachers with toxic and non-toxic classroom samples. The half maximal effective concentration $\left(\mathrm{EC}_{50}\right)$ indicates the degree of toxicity (ie, the lower the $\mathrm{EC}_{50}$, the higher the toxicity). N.D., not definable. ${ }^{a}$ These symptoms were not reported by teachers in the group of non-toxic microbes, so OR could not be calculated.

Allergic rhinitis was significantly more common among teachers in toxic classrooms with regard to dust sample results (Table 2). 


\section{Discussion}

Our results show variations in intrinsic toxicities in settled dusts and fungal biomass from fallout plates collected from 231 classrooms in 15 schools in the city of Helsinki, Finland. $41 \%$ of the cultured microbial fallout samples and $34 \%$ of the wiped dust samples in classrooms were toxic in vitro. Our results suggest that exposure to toxic dust and microbes increases the risk of teachers' work-related symptoms.

In our series, significant toxicity-related symptoms were typically linked with the respiratory tract (nose stuffiness, nose dryness, nose stinging, runny nose, allergic rhinitis, mouth dryness, hoarseness, sore throat, globus sensation, throat mucus, throat itching, shortness of breath, and dry cough) and eyes (wet eyes and eye discharge). Our results show that some of the work-related symptoms were significantly associated with both dust and microbial toxicities, whereas some toxicity-associated symptoms were identified only by dust or microbial analyses, suggesting differences in exposure or activation of body responses.

Toxic indoor exposure is a complex phenomenon [16,27,52-55]. Microbial toxins are known to be present in non-industrial buildings, but concentrations of individual toxins are typically low [21-23]. However, in addition to hundreds of known microbial toxins, new ones are still identified. Furthermore, a huge number of different toxic chemicals have been found in indoor dust, such as plasticizers, flame retardants, polycyclic aromatic hydrocarbons, pesticides, and other biocides [56]. The toxic properties of many chemicals are not yet known [57]. Chemical assays cannot determine the harmfulness of total exposure to microbial and anthropogenic toxins or their interactions. Thus, bioassays providing an integrated picture of overall toxicity are essential tools for understanding toxic mechanisms, detecting known and unknown toxins, and studying the potential health relevance of complex toxic exposure [37,57-60]. However, sensitivity and specificity varies in different bioassays, and there is no single comprehensive method for detecting all potentially adverse effects of indoor air on human health.

BSMI assay has been identified as a sensitive biosensor of microbial toxins in buildings associated with health complaints and food poisonings [12,16,43,46,53]. Toxicity detected in fallout plates may indicate dominance of bacteria producing sperm-toxic substances—such as the mitochondriotoxins produced by Streptomycetes, Bacillus, and Paenibacillus, $[9,16,38,43,45,53,58]$ — and also toxins affecting ion homeostasis and energy metabolism produced by the fungal genera Chaetomium, Stachybotrys, mycoparasitic Trichoderma species and toxigenic Paecilomyces, Aspergillus and Penicillium species [10-12,46]. Many of these species and genera are recognized as indicators of water damage to buildings [61,62]. The mycoparasitic genus Trichoderma feed on fungi colonizing indoor spaces, and may indicate mold growth in building structures $[10,41,63]$. It was interesting to note that in toxic fallout plates there were significantly more mycoparasitic and mycotrophic Trichoderma isolates than in non-toxic plates.

Mitochondrial toxins affecting cellular energy metabolism and ion homeostasis cause sublethal injury, which can be demonstrated by a decreased motility in boar sperm [53,64-66]. In addition to a wide variety of different microbial toxins, also environmental pollutants, biocides, consumer chemicals, tobacco smoke, and particulate matter can damage mitochondria [47,67-72]. We have earlier seen that there was no correlation between dust and microbial toxicities [51], and we suggested that dust toxicity was at least partially derived from the environmental chemicals, whereas microbial culture toxicity directly expresses microbial toxicity.

Mitochondria play an important role in human physiological regulatory mechanisms [73,74]. In addition to energy production and cellular calcium regulation, mitochondria have a central role in the regulation of the inflammatory response through production of reactive oxygen species (mtROS) and activation of the NLRP3 inflammasome [75,76]. Mitochondrial dysfunction and ROS-mediated oxidative stress are associated with the pathophysiology of many chronic inflammatory diseases, such as asthma, and chronic obstructive pulmonary disease, as well as Alzheimer's and Parkinson's diseases [77-79]. 
Moreover, environmental mitochondriotoxic exposure has been suggested to be a significant causal factor for these diseases [68,69,71,76,80-84].

Microbial toxins cause immunological inflammation, especially in combination with other exposures, such as to lipopolysaccharides (LPS) [9,33,40,85]. Pro-inflammatory cytokines have been found to interfere with mitochondrial function [86]. Transient receptor potential (TRP) channels in the chemosensory trigeminal C-fibers innervating the nasal cavity, throat, and conjunctiva and in the vagal C-fibers innervating the lower respiratory tract can sense irritating and toxic chemicals $[87,88]$. The sperm-toxic microbial toxin antimycin A has been shown to cause mitochondrial dysfunction, mtROS production, and C-fiber activation via TRP channels in experimental mice models [89-91]. When exposed to mtROS - even non-toxic concentrations of chemicals, LPS, or inflammatory mediatorsthis chemosensory system can induce neurogenic inflammation via neuropeptide secretion and mast cell degranulation [90,92-98].

The majority of the 18 boar sperm toxicity-related symptoms may be due to one or more of these three mechanisms (1) mitochondrial dysfunction / oxidative stress, (2) immunological inflammation, and (3) chemosensory C-fibers. Five symptoms (headache, throat mucus and itching, shortness of breath, and cough) may be activated via all three mechanisms [99-111], six symptoms (stuffy and runny nose, hoarseness, sore throat, globus sensation, watery eyes) via immunological inflammation and C-fibers [99,106,112-119], and one symptom (difficulty falling asleep) via mitochondrial dysfunction and immunological inflammation [120-122]. Eye discharge and increased need for sleep can be triggered due to immunological inflammation [119-121], and nasal stinging via C-fibers [88]. Only three symptoms associated with boar sperm toxicity (dry nose and mouth, sound hypersensitivity) did not appear to be related to these three mechanisms according to thus far published literature. This strong overlap supports the hypothesis that mitochondrial dysfunction, immunological inflammation, and chemosensory C-fibers are involved in the pathophysiology of boar sperm toxicity-related symptoms.

Respiratory protection from toxic particles is significantly based on airway mucociliary clearance [123]. However, microbial toxins can inhibit the motility of cilia, just as occurs with exposure to tobacco smoke $[59,124,125]$. The airway particle load is directed mostly to the upper respiratory tract [126]. Upper respiratory symptoms were also most common among teachers' toxicity-related symptoms in our series.

Axonal transport of the olfactory and trigeminal nerves and bulk flow through the perivascular space provide direct access to toxic exposures from the nasal cavity to the brain, which bypasses the blood-brain barrier [127]. The importance of mitochondrial toxicity and the nose-to-brain route has been demonstrated in an experimental model by nasal administration of mitochondriotoxic MPTP to induce Parkinson's disease in mice [128]. Toxic exposures may also be transferred from the respiratory tract into systemic circulation, thus bypassing hepatic first-pass metabolism $[126,129]$. Thus, adverse inhalation exposure to lipophilic mitochondriotoxins may potentially cause consequences in any part of the body.

Although the pathogenesis of BRS thus far remains open, our results show that teachers have dust and microbial toxicity-associated symptoms in toxic classrooms demonstrated by BSMI assay. This assay also detects mitochondrial dysfunction, which could explain how BRS may be initiated. Several mechanisms are likely involved in the inhibition of these mechanisms, such as the anti-inflammatory effect of CGRP secreted by C-fibers [130]. Further studies are needed to explore the possible presence of mitochondrial dysfunction and oxidative stress, activation, and peripheral sensitization of chemosensory C-fibers, and neuro-immune crosstalk in those exposed to mitochondriotoxic microbes and chemicals in indoor environments. A possible link between these physiological systems and work-related symptoms is described in Figure 2. 


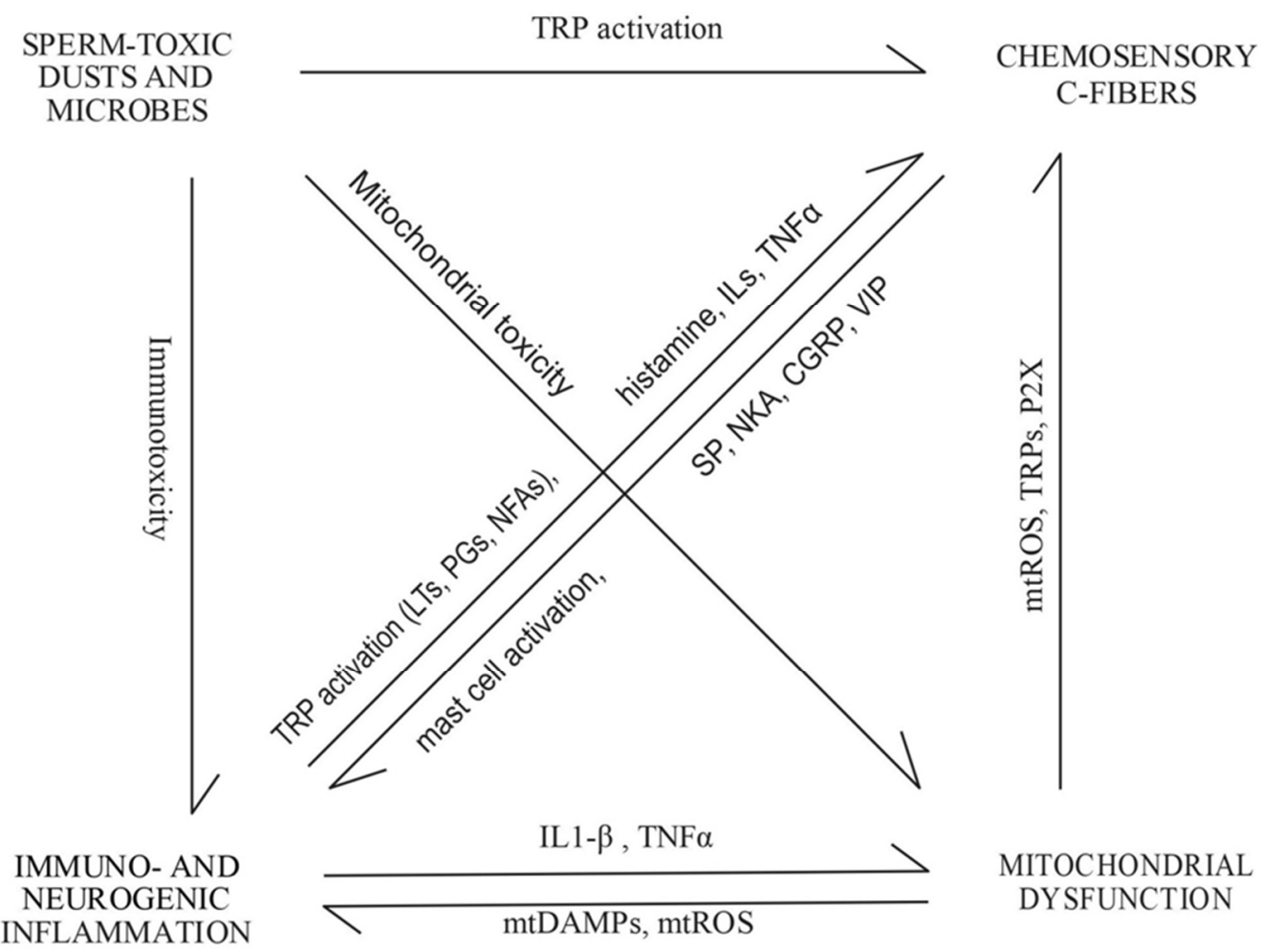

Figure 2. Hypothetical model of pathophysiological processes triggered by sperm-toxic dusts and microbes. The workrelated symptoms are probably due to activation of described mechanisms and their interactions. Abbreviations: TRPtransient receptor potential channels; LTs—leukotrienes; PGs—prostaglandins; NFAs—nitrated fatty acids; ILs—interleukins, IL-1 $\beta$-interleukin 1beta; TNF $\alpha$-tumor necrosis factor alpha; SP—substance P; NKA—neurokinin A; CGRP—calcitonin gene-related peptides; VIP_-vasoactive intestinal peptide; $\mathrm{mtROS}$ - mitochondria-derived reactive oxygen species; $\mathrm{P} 2 \mathrm{X}$ purinergic $2 \mathrm{X}$ receptor; $\mathrm{mtDAMPs}$ - mitochondrial damage-associated molecular patterns.

Our study had some limitations. In this series, toxicity analyses were performed only for teachers' current principal classrooms, while data related to exposures in other areas of school, home, and previous work places were not available. The low proportion of men $(18 \%)$ weakens the assessment of the association between toxicity and symptoms in men. Furthermore, our sampling methods did not allow us to analyze the exact amount of teachers' exposure, and BSMI assay is insensitive to many types of toxins-e.g., toxins affecting macromolecular syntheses and several mycotoxins such as sterigmatocystine and ochratoxin [46]. Quantities of toxic microbes in indoor air were not determined and systematic identification of toxic microbes was not performed. Other exposures potentially provoking symptoms - such as volatile organic compounds, room temperature, insufficient ventilation rate, or high carbon dioxide concentration - were not measured concurrently. However, although we only tested the teachers' current principal classrooms, we found a significant association between symptoms and measured toxicity in settled dust and cultured airborne microbial biomass.

A main strength of our study was an in vitro model that has been successfully used to identify toxin producers in buildings with health complaints, and that measures a significant mechanism of environmental toxicity. Two independent sampling methods were used in the study. Due to the strong tendency of microbial toxins to aerosolize, especially in airflow $[11,16,17,20]$, we ruled out high airflows (e.g., vacuum cleaner) for dust sampling or sample processing to ensure that toxins were not lost from samples. We also used ethanol to extract dust and microbial samples, because a large proportion of microbial toxins and indoor chemicals are lipophilic and potentially bioaccumulative [56,131]. In addition, we made a comparison based on teachers' individual workspace toxicity instead of a buildinglevel comparison. Examining the association between individual symptoms and toxicity 
allowed a preliminary assessment of a hypothetical model of the pathophysiological mechanisms involved in sperm-toxic exposure.

Teachers did not know the toxicities of their classrooms, which reduced the risk of information bias. The study population was also comparable. Teachers belonged to the same profession and the same socio-economic class, worked in the same city, and clear inclusion criteria were defined in the study. The Real Estate Department of the City of Helsinki selected the schools to represent the actual age and condition distribution of the city's schools.

In conclusion, our results show a clear variation in in vitro toxicity in classroom environments as measured by the BSMI assay, a sensitive indicator of mitochondrial toxicity. The risk of various work-related symptoms, especially respiratory and ocular symptoms, was strongly increased among exposed teachers in classrooms with toxic dust and airborne microbes. These findings provide a new perspective for the research field of indoor adverse exposure and pathophysiological processes in exposed, symptomatic individuals. This approach can also be used in real life for detection of adverse occupational exposures at individual or organizational levels.

\section{Materials and Methods}

Materials and methods have been presented in more detail previously [50,51]. Here we present a short summary of a sub-analysis of the same dataset.

\subsection{Schools}

Fifteen schools representing construction, building services, and ventilation systems from different decades, some of which had been renovated, were selected by the Real Estate Department of the City of Helsinki. A more detailed description of schools has been presented previously [50]. The schools were built in 1924-2004 and one building was renovated in 2009. Fourteen schools had an area of $2400-8300 \mathrm{~m}^{2}$ and one school $474 \mathrm{~m}^{2}$. Concrete was the main structural material for all the schools. Thirteen schools had a mechanical exhaust air system, eight schools also had a mechanical supply air system, and one had completely natural ventilation. Several moisture damage and indoor air studies had been required in eight of the schools, one study in one school, and no concern for indoor air quality or moisture damage had been identified in six schools. This building-level information was not available to the research team during the research project.

\subsection{Teachers}

Teachers were eligible for the study if they worked at least seven hours a week in the school under study and for at least one year in the same classroom; they were not pregnant at the time of the study; and information was available about their workspace. The symptoms of students in these schools were not studied.

We sent a questionnaire to all the teachers in the 15 schools. Demographics included age, gender, smoking status, and atopy. The survey asked whether symptoms had occurred in the last 12 months. If the teacher had answered that the symptom was related to time spent in the workplace, his/her symptom was classified as work-related. In addition to all known BRS, all other symptoms with a prevalence of at least $10 \%$ and concomitant work-relatedness of at least $50 \%$ were also selected for analysis.

The privacy of the subjects was protected by conducting the survey anonymously, thus no personal identity information was collected. According to the Ethics Committee of Helsinki University Hospital, no formal approval was required for this type of anonymous study.

\subsection{Indoor Samples}

Two types of indoor samples (wiped dust and airborne microbes) were collected from each teacher's principal school classroom [50,51]. Cotton balls were used to wipe 
dust samples from surfaces above the floor (e.g., above lamps and cabinets) that had last been cleaned 8-12 months earlier. Airborne microbial propagules were collected by allowing them to fall onto malt extract agar (MEA) plates for a sampling time of $1 \mathrm{~h}$. Malt extract agars (malt extract 70167, Sigma-Aldrich, Merck KGaA, Darmstadt, Germany; agar 05039, Sigma-Aldrich, Merck KGaA, Darmstadt, Germany) were incubated at $22-24{ }^{\circ} \mathrm{C}$. After 4-6 weeks of incubation, all plates were photographed and microbial biomasses were collected. Colony-forming units were not counted, but recognizable species were identified from the photographs of microbial cultures (Figure 1). To treat these two different types of samples, the wiped dust and microbial biomasses were extracted into ethanol and evaporated to dryness at $62{ }^{\circ} \mathrm{C}$. The residues were then re-dissolved in ethanol to a concentration of $10 \mathrm{mg}$ dry weight/mL [16]. Next, boar sperm were exposed to extracts of wiped dust and microbial mass for three days [50,51].

\subsection{Toxicity Assay}

Toxicity of the extracts was tested with the classical ex vivo BSMI assay measuring sublethal toxicity as sperm motility inhibition. The BSMI assay measures inability to respond to induction of motility in resting immotile toxin-exposed sperm cells and has been described in detail earlier [12,52,53]. In brief, after exposure for three days at $22-24{ }^{\circ} \mathrm{C}$, motility was induced in the exposed sperm cells by shaking to provide the sperm cells with oxygen and warming to $37^{\circ} \mathrm{C}$ for $5 \mathrm{~min}$. The induced sperm motility, i.e., progressive and rapid motility, was assessed using a phase contrast microscope with a warmed stage $\left(37^{\circ} \mathrm{C}\right)$ as described earlier [50]. Progressive and rapid motility was subjectively estimated as the proportion of spermatozoa exhibiting high amplitude tail beating (Figure 3A), which is required for progressive and rapid sperm motility. This is easily visualized as rapid swirling motility comparable to mass activity in a microscopic frame [53]. Static, shivering, or slowly motile sperm cells express no amplitude or low amplitude of tail beating (Figure 3B,C).

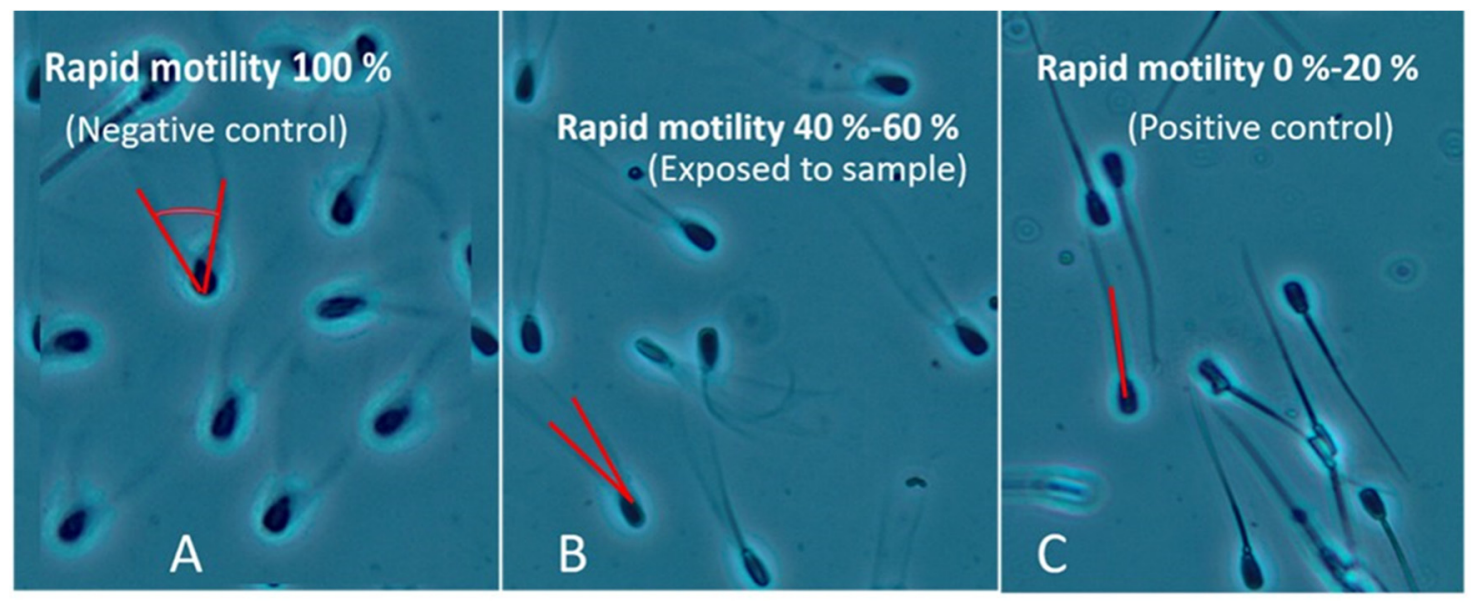

Figure 3. Estimation of sperm motility. Phase contrast micrographs visualizing different amplitudes of tail beating in boar sperm. The vehicle-exposed sperm cells in Panel (A) express high amplitude tail beating visible to the human eye as an artefact consisting of two tails. The angle between the tails is $>40^{\circ}$ and the majority of the sperm cells exhibit rapid and progressive motility. Panel (B) shows sperm cells with low amplitude tail beating, the angle between two tails is less than $20^{\circ}$ and the swimming speed/the number of rapidly swimming sperm cells is reduced by $50 \%$ compared to the cells in Panel (A). Panel (C) shows the immobilized sperm cells of the positive control. In this panel, only a few sperm cells moved at all and no sperm cells with two tails were visible. 
The half maximal effective concentration $\left(\mathrm{EC}_{50}\right)$ indicated the level of toxicity (i.e., the lower the $\mathrm{EC}_{50}$, the higher the toxicity). The $\mathrm{EC}_{50}$ concentration of the ethanol-extracted dry substances in the dust- and microbial extracts is defined as the lowest concentration at which $\geq 50 \%$ of sperm had lost rapid and progressive motility relative to the solvent vehicle, ethanol. The motility of the ethanol-exposed sperm cells was estimated as the reference value of $100 \%$, representing the negative control in each test. Sperm cells immobilized by exposure to triclosan exhibiting motility close to $0 \%$ were used as positive controls [37,50].

The $\mathrm{EC}_{50}\left(<50 \%\right.$ motility) was estimated as the concentration between $\mathrm{EC}_{<20}$ (motility $>80 \%$ compared to the control, meaning similar to the negative control) and $\mathrm{EC}_{80}$ (motility $<20 \%$, similar to the immobilized control). When testing $>200$ extracts, this protocol gave $99 \%$ similarity to measurements of the proportion of rapidly motile spermatozoa done with a Hamilton Thorne sperm analyzer (HTM-S, ver. 7.2; Hamilton-Thorn Research, Danvers, MA, USA). When calibrated with triclosan (Sigma Chemical Co., St. Louis, MO, USA) in 10 parallel tests, the $\mathrm{EC}_{50}$ was $1 \mu \mathrm{g} / \mathrm{mL}(\mathrm{SD} \pm 0.2)[37,52]$.

\subsection{Statistical Analysis}

The effect of toxicity on the presence of different symptoms was analyzed using a logistic regression model. The results of the logistic regression analyses are presented with odds ratios (ORs) with 95\% confidence intervals (CIs). Age, sex, current smoking status, and atopy as potential confounding factors were used as adjusting variables when judging the effects of the toxicity outcomes of the classroom samples on the presence of different symptoms. In the adjustment, age was divided into four categories ( $\leq 34,35-44,45-54$, and $\geq 55$ years), while sex, smoking status, and atopy were dichotomous. The presence of symptoms was divided into two categories (yes or no). Dust toxicity was divided into three categories $\left(\mathrm{EC}_{50} \geq 25,12\right.$, and $\left.\leq 6 \mu \mathrm{g} / \mathrm{mL}\right)$ and microbial toxicity into two categories $\left(\mathrm{EC}_{50}\right.$ $>12$ and $\leq 12 \mu \mathrm{g} / \mathrm{mL}$ ). Categorical data was analyzed using Fisher's exact test. Two-tailed $p$ values are reported. All analyses were performed with SPSS for Windows (IBM Corp. Released 2019. IBM SPSS Statistics for Windows, Version 26.0. Armonk, NY: IBM Corp.).

Supplementary Materials: The following are available online at https:/ / www.mdpi.com/article/10 .3390 / pathogens10111360/s1, Table S1: title, The results of the crude logistic regression models for the impact of increased toxicity levels of wiped dust in the classroom on work-related symptoms.; Table S2: The results of the crude logistic regression models for the impact of toxicity of airborne microbes in the classroom on work-related symptoms.

Author Contributions: Conceptualization, J.S., P.O., M.A.A. and H.S.; methodology, J.S., P.O., M.A.A. and H.S.; software, J.S. and P.O.; validation, J.S., P.O., M.A.A. and H.S.; formal analysis, J.S. and P.O.; investigation, J.S., P.O., M.A.A. and H.S.; resources, J.S., P.O., M.A.A. and H.S.; data curation, J.S. and P.O.; writing - original draft preparation, J.S., P.O., M.A.A. and H.S.; writing-review and editing, J.S., P.O., M.A.A. and H.S.; visualization, J.S. and M.A.A.; supervision, H.S.; project administration, H.S.; funding acquisition, J.S. All authors have read and agreed to the published version of the manuscript.

Funding: This work was supported by the Finnish Work Environment Fund (grant 200262). The funders had no role in the study design, data collection, data analysis, data interpretation, in the writing of the report or in the decision to submit the article for publication.

Institutional Review Board Statement: Approval was waived by the Ethics Committee of Helsinki University Hospital. The Ethics Committee stated that no formal approval was required for this type of anonymous study.

Informed Consent Statement: Not applicable.

Data Availability Statement: Data supporting reported results are available upon reasonable request from the correspondence author.

Acknowledgments: We acknowledge grant from the Finnish Work Environment Fund (TSR 200262).

Conflicts of Interest: J.S. owns 3\% of company shares in Inspector Sec Ltd. P.O., M.A., and H.S. declare no conflict of interest. 


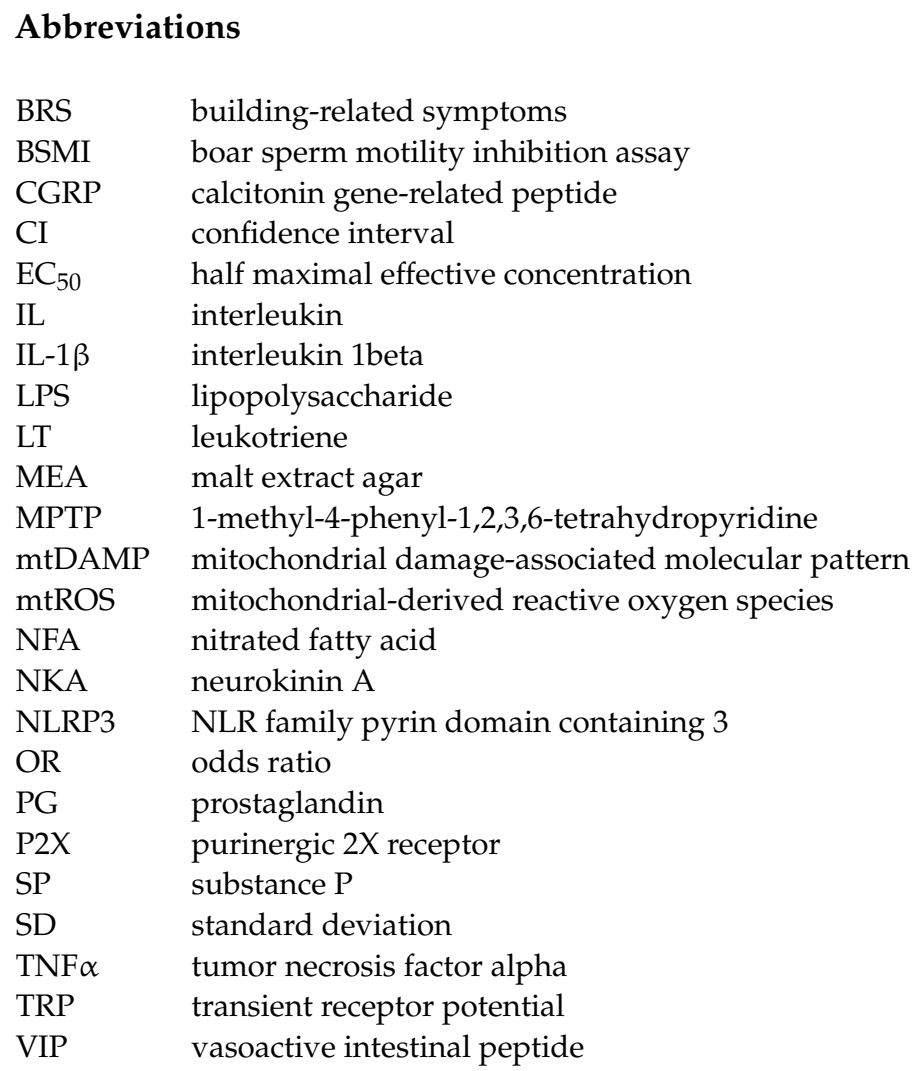

\section{References}

1. World Health Organisation. WHO Guidelines for Indoor Air Quality: Dampness and Mould; World Health Organization: Geneva, Swithzerland, 2009; pp. 93-95.

2. Burge, S.; Hedge, A.; Wilson, S.; Bass, J.H.; Robertson, A. Sick building syndrome: A study of 4373 office workers. Ann. Occup. Hyg. 1987, 31, 493-504.

3. World Health Organisation. Indoor Air Pollutants: Exposure and Health Effects; EURO Reports and Studies 78; World Health Organization: Copenhagen, Denmark, 1983; pp. 23, 25.

4. Mendell, M.J.; Mirer, A.G.; Cheung, K.; Tong, M.; Douwes, J. Respiratory and allergic health effects of dampness, mold, and dampness-related agents: A review of the epidemiologic evidence. Environ. Health Perspect. 2011, 119, 748-756. [CrossRef] [PubMed]

5. Quansah, R.; Jaakkola, M.S.; Hugg, T.T.; Heikkinen, S.A.; Jaakkola, J.J. Residential dampness and molds and the risk of developing asthma: A systematic review and meta-analysis. PLoS ONE 2012, 7, e47526. [CrossRef] [PubMed]

6. Jaakkola, M.S.; Quansah, R.; Hugg, T.T.; Heikkinen, S.A.; Jaakkola, J.J. Association of indoor dampness and molds with rhinitis risk: A systematic review and meta-analysis. J. Allergy Clin. Immunol. 2013, 132, 1099-1110. [CrossRef] [PubMed]

7. $\quad$ Engelhart, S.; Loock, A.; Skutlarek, D.; Sagunski, H.; Lommel, A.; Färber, H.; Exner, M. Occurrence of toxigenic Aspergillus versicolor isolates and sterigmatocystin in carpet dust from damp indoor environments. Appl. Environ. Microbiol. 2002, 68, 3886-3890. [CrossRef] [PubMed]

8. Hirvonen, M.R.; Huttunen, K.; Roponen, M. Bacterial strains from moldy buildings are highly potent inducers of inflammatory and cytotoxic effects. Indoor Air 2005, 15, 65-70. [CrossRef]

9. Rasimus-Sahari, S.; Teplova, V.V.; Andersson, M.A.; Mikkola, R.; Kankkunen, P.; Matikainen, S.; Gahmberg, C.G.; Andersson, L.C.; Salkinoja-Salonen, M. The peptide toxin amylosin of Bacillus amyloliquefaciens from moisture-damaged buildings is immunotoxic, induces potassium efflux from mammalian cells, and has antimicrobial activity. Appl. Environ. Microbiol. 2015, 81, 2939-2949. [CrossRef] [PubMed]

10. Castagnoli, E.; Marik, T.; Mikkola, R.; Kredics, L.; Andersson, M.A.; Salonen, H.; Kurnitski, J. Indoor Trichoderma strains emitting peptaibols in guttation droplets. J. Appl. Microbiol. 2018, 125, 1408-1422. [CrossRef] [PubMed]

11. Salo, J.; Marik, T.; Mikkola, R.; Andersson, M.A.; Kredics, L.; Salonen, H.; Kurnitski, J. Penicillium expansum strain isolated from indoor building material was able to grow on gypsum board and emitted guttation droplets containing chaetoglobosins and communesins A, B and D. J. Appl. Microbiol. 2019, 127, 1135-1147. [CrossRef] [PubMed]

12. Salo, J.; Kedves, O.; Mikkola, R.; Kredics, L.; Andersson, M.A.; Kurnitski, J.; Salonen, H. Detection of Chaetomium globosum, Ch. cochliodes and Ch. rectangulare during the Diversity Tracking of Mycotoxin-Producing Chaetomium-Like Isolates Obtained in Buildings in Finland. Toxins 2020, 12, 443. [CrossRef] 
13. Brasel, T.L.; Martin, J.M.; Carriker, C.G.; Wilson, S.C.; Straus, D.C. Detection of airborne Stachybotrys chartarum macrocyclic trichothecene mycotoxins in the indoor environment. Appl. Environ. Microbiol. 2005, 71, 7376-7388. [CrossRef]

14. Lemons, A.R.; Croston, T.L.; Goldsmith, W.T.; Barnes, M.A.; Jaderson, M.A.; Park, J.H.; McKinney, W.; Beezhold, D.H.; Green, B.J. Cultivation and aerosolization of Stachybotrys chartarum for modeling pulmonary inhalation exposure. Inhal. Toxicol. 2019, 31, 446-456. [CrossRef]

15. Brasel, T.L.; Douglas, D.R.; Wilson, S.C.; Straus, D.C. Detection of airborne Stachybotrys chartarum macrocyclic trichothecene mycotoxins on particulates smaller than conidia. Appl. Environ. Microbiol. 2005, 71, 114-122. [CrossRef]

16. Andersson, M.A.; Mikkola, R.; Rasimus, S.; Hoornstra, D.; Salin, P.; Rahkila, R.; Heikkinen, M.; Mattila, S.; Peltola, J.; Kalso, S.; et al. Boar spermatozoa as a biosensor for detecting toxic substances in indoor dust and aerosols. Toxicol. Vitr. 2010, 24, 2041-2052 [CrossRef] [PubMed]

17. Aleksic, B.; Draghi, M.; Ritoux, S.; Bailly, S.; Lacroix, M.; Oswald, I.P.; Bailly, J.D.; Robine, E. Aerosolization of Mycotoxins after Growth of Toxinogenic Fungi on Wallpaper. Appl. Environ. Microbiol. 2017, 83, e01001-17. [CrossRef] [PubMed]

18. Gareis, M.; Gareis, E.M. Guttation droplets of Penicillium nordicum and Penicillium verrucosum contain high concentrations of the mycotoxins ochratoxin A and B. Mycopathologia 2007, 163, 207-214. [CrossRef] [PubMed]

19. Gareis, M.; Gottschalk, C. Stachybotrys spp. and the guttation phenomenon. Mycotoxin Res. 2014, 30, 151-159. [CrossRef] [PubMed]

20. Andersson, M.A.; Salo, J.; Kedves, O.; Kredics, L.; Druzhinina, I.; Kurnitski, J.; Salonen, H. Bioreactivity, Guttation and Agents Influencing Surface Tension of Water Emitted by Actively Growing Indoor Mould Isolates. Microorganisms 2020, 8, E1940. [CrossRef]

21. Bloom, E.; Nyman, E.; Must, A.; Pehrson, C.; Larsson, L. Molds and mycotoxins in indoor environments-a survey in waterdamaged buildings. J. Occup. Environ. Hyg. 2009, 6, 671-678. [CrossRef]

22. Täubel, M.; Sulyok, M.; Vishwanath, V.; Bloom, E.; Turunen, M.; Järvi, K.; Kauhanen, E.; Krska, R.; Hyvärinen, A.; Larsson, L.; et al. Co-occurrence of toxic bacterial and fungal secondary metabolites in moisture-damaged indoor environments. Indoor Air 2011, 21, 368-375. [CrossRef] [PubMed]

23. Peitzsch, M.; Sulyok, M.; Täubel, M.; Vishwanath, V.; Krop, E.; Borràs-Santos, A.; Hyvärinen, A.; Nevalainen, A.; Krska, R.; Larsson, L. Microbial secondary metabolites in school buildings inspected for moisture damage in Finland, The Netherlands and Spain. J. Environ. Monit. 2012, 14, 2044-2053. [CrossRef]

24. Došen, I.; Andersen, B.; Phippen, C.B.; Clausen, G.; Nielsen, K.F. Stachybotrys mycotoxins: From culture extracts to dust samples. Anal. Bioanal. Chem. 2016, 408, 5513-5526. [CrossRef] [PubMed]

25. Park, J.H.; Sulyok, M.; Lemons, A.R.; Green, B.J.; Cox-Ganser, J.M. Characterization of fungi in office dust: Comparing results of microbial secondary metabolites, fungal internal transcribed spacer region sequencing, viable culture and other microbial indices. Indoor Air 2018. online ahead of print. [CrossRef] [PubMed]

26. Viegas, C.; Almeida, B.; Monteiro, A.; Paciência, I.; Rufo, J.C.; Carolino, E.; Quintal-Gomes, A.; Twarużek, M.; Kosicki, R.; Marchand, G.; et al. Settled dust assessment in clinical environment: Useful for the evaluation of a wider bioburden spectrum. Int. J. Environ. Health Res. 2019, 1-19. [CrossRef]

27. Viegas, S.; Viegas, C.; Martins, C.; Assunção, R. Occupational Exposure to Mycotoxins-Different Sampling Strategies Telling a Common Story Regarding Occupational Studies Performed in Portugal (2012-2020). Toxins 2020, 12, 513. [CrossRef]

28. Polizzi, V.; Delmulle, B.; Adams, A.; Moretti, A.; Susca, A.; Picco, A.M.; Rosseel, Y.; Kindt, R.; Van Bocxlaer, J.; De Kimpe, N.; et al. JEM Spotlight: Fungi, mycotoxins and microbial volatile organic compounds in mouldy interiors from water-damaged buildings. J. Environ. Monit. 2009, 11, 1849-1858. [CrossRef] [PubMed]

29. Allermann, L.; Pejtersen, J.; Gunnarsen, L.; Poulsen, O.M. Building-related symptoms and inflammatory potency of dust from office buildings. Indoor Air 2007, 17, 458-467. [CrossRef] [PubMed]

30. Tirkkonen, J.; Täubel, M.; Hirvonen, M.R.; Leppänen, H.; Lindsley, W.G.; Chen, B.T.; Hyvärinen, A.; Huttunen, K. Evaluation of sampling methods for toxicological testing of indoor air particulate matter. Inhal. Toxicol. 2016, 28, 500-507. [CrossRef] [PubMed]

31. Roponen, M.; Meklin, T.; Rintala, H.; Hyvärinen, A.; Hirvonen, M.R. Effect of moisture-damage intervention on the immunotoxic potential and microbial content of airborne particles and on occupants' upper airway inflammatory responses. Indoor Air 2013, 23, 295-302. [CrossRef]

32. Huttunen, K.; Tirkkonen, J.; Täubel, M.; Krop, E.; Mikkonen, S.; Pekkanen, J.; Heederik, D.; Zock, J.P.; Hyvärinen, A.; Hirvonen, M.R. Inflammatory potential in relation to the microbial content of settled dust samples collected from moisture-damaged and reference schools: Results of HITEA study. Indoor Air 2016, 26, 380-390. [CrossRef]

33. Allermann, L.; Meyer, H.W.; Poulsen, O.M.; Nielsen, J.B.; Gyntelberg, F. Inflammatory potential of dust from schools and building related symptoms. Occup. Environ. Med. 2003, 60, E5. [CrossRef] [PubMed]

34. Huttunen, K.; Rintala, H.; Hirvonen, M.R.; Vepsalainen, A.; Hyvarinen, A.; Meklin, T.; Toivola, M.; Nevalainen, A. Indoor air particles and bioaerosols before and after renovation of moisture-damaged buildings: The effect on biological activity and microbial flora. Environ. Res. 2008, 107, 291-298. [CrossRef] [PubMed]

35. Tirkkonen, J.; Täubel, M.; Leppänen, H.; Peltonen, M.; Lindsley, W.; Chen, B.T.; Hyvärinen, A.; Hirvonen, M.R.; Huttunen, K. Toxicity of airborne dust as an indicator of moisture problems in school buildings. Inhal. Toxicol. 2017, 29, 75-81. [CrossRef] [PubMed] 
36. Huttunen, K.; Wlodarczyk, A.J.; Tirkkonen, J.; Mikkonen, S.; Täubel, M.; Krop, E.; Jacobs, J.; Pekkanen, J.; Heederik, D.; Zock, J.P.; et al. Oxidative capacity and hemolytic activity of settled dust from moisture-damaged schools. Indoor Air 2019, 29, 299-307. [CrossRef] [PubMed]

37. Andersson, M.A.; Nikulin, M.; Koljalg, U.; Andersson, M.C.; Rainey, F.; Reijula, K.; Hintikka, E.L.; Salkinoja-Salonen, M. Bacteria, molds, and toxins in water-damaged building materials. Appl. Environ. Microbiol. 1997, 63, 387-393. [CrossRef]

38. Andersson, M.A.; Mikkola, R.; Kroppenstedt, R.M.; Rainey, F.A.; Peltola, J.; Helin, J.; Sivonen, K.; Salkinoja-Salonen, M.S. The mitochondrial toxin produced by Streptomyces griseus strains isolated from an indoor environment is valinomycin. Appl. Environ. Microbiol. 1998, 64, 4767-4773. [CrossRef]

39. Andersson, M.A.; Mikkola, R.; Raulio, M.; Kredics, L.; Maijala, P.; Salkinoja-Salonen, M.S. Acrebol, a novel toxic peptaibol produced by an Acremonium exuviarum indoor isolate. J. Appl. Microbiol. 2009, 106, 909-923. [CrossRef]

40. Kankkunen, P.; Rintahaka, J.; Aalto, A.; Leino, M.; Majuri, M.L.; Alenius, H.; Wolff, H.; Matikainen, S. Trichothecene mycotoxins activate inflammatory response in human macrophages. J. Immunol. 2009, 182, 6418-6425. [CrossRef] [PubMed]

41. Mikkola, R.; Andersson, M.A.; Kredics, L.; Grigoriev, P.A.; Sundell, N.; Salkinoja-Salonen, M.S. 20-Residue and 11-residue peptaibols from the fungus Trichoderma longibrachiatum are synergistic in forming $\mathrm{Na}+/ \mathrm{K}+-$ permeable channels and adverse action towards mammalian cells. FEBS J. 2012, 279, 4172-4190. [CrossRef]

42. Mikkola, R.; Andersson, M.A.; Hautaniemi, M.; Salkinoja-Salonen, M.S. Toxic indole alkaloids avrainvillamide and stephacidin B produced by a biocide tolerant indoor mold Aspergillus westerdijkiae. Toxicon 2015, 99, 58-67. [CrossRef]

43. Peltola, J.; Andersson, M.A.; Haahtela, T.; Mussalo-Rauhamaa, H.; Rainey, F.A.; Kroppenstedt, R.M.; Samson, R.A.; SalkinojaSalonen, M.S. Toxic-metabolite-producing bacteria and fungus in an indoor environment. Appl. Environ. Microbiol. 2001, 67, 3269-3274. [CrossRef]

44. Peltola, J.; Niessen, L.; Nielsen, K.F.; Jarvis, B.B.; Andersen, B.; Salkinoja-Salonen, M.; Möller, E.M. Toxigenic diversity of two different RAPD groups of Stachybotrys chartarum isolates analyzed by potential for trichothecene production and for boar sperm cell motility inhibition. Can. J. Microbiol. 2002, 48, 1017-1029. [CrossRef] [PubMed]

45. Mikkola, R.; Andersson, M.A.; Grigoriev, P.; Heinonen, M.; Salkinoja-Salonen, M.S. The toxic mode of action of cyclic lipodepsipeptide fusaricidins, produced by Paenibacillus polymyxa, toward mammalian cells. J. Appl. Microbiol. 2017, 123, 436-449. [CrossRef]

46. Salo, J.; Marik, T.; Bencsik, O.; Mikkola, R.; Kredics, L.; Szekeres, A.; Andersson, M.A.; Salonen, H.; Kurnitski, J. Screening Mold Colonies by Using Two Toxicity Assays Revealed Indoor Strains of Aspergillus calidoustus Producing Ophiobolins G and K. Toxins 2019, 11, 683. [CrossRef] [PubMed]

47. Ajao, C.; Andersson, M.A.; Teplova, V.V.; Nagy, S.; Gahmberg, C.G.; Andersson, L.C.; Hautaniemi, M.; Kakasi, B.; Roivainen, M.; Salkinoja-Salonen, M. Mitochondrial toxicity of triclosan on mammalian cells. Toxicol. Rep. 2015, 2, 624-637. [CrossRef] [PubMed]

48. Toxicities of Detergents Used in Cleaning Chemicals and Hygiene Products in a Test Battery of Ex Vivo and In Vitro Assays. Updated 2019. Available online: https://www.researchgate.net/publication/332180207_FSdetergentpaper (accessed on 12 April 2021).

49. Hyvönen, S.; Syrjala, H. Asthma Case Cluster during Renovation of a Water-Damaged and Toxic Building. Microorganisms 2019, 7, 642. [CrossRef] [PubMed]

50. Salin, J.T.; Salkinoja-Salonen, M.; Salin, P.J.; Nelo, K.; Holma, T.; Ohtonen, P.; Syrjälä, H. Building-related symptoms are linked to the in vitro toxicity of indoor dust and airborne microbial propagules in schools: A cross-sectional study. Environ. Res. 2017, 154, 234-239. [CrossRef] [PubMed]

51. Salin, J.T.; Ohtonen, P.; Syrjälä, H. Teachers' work-related non-literature-known building-related symptoms are also connected to indoor toxicity: A cross-sectional study. Indoor Air 2021, 31, 1533-1539. [CrossRef] [PubMed]

52. Bencsik, O.; Papp, T.; Berta, M.; Zana, A.; Forgó, P.; Dombi, G.; Andersson, M.A.; Salkinoja-Salonen, M.; Vágvölgyi, C.; Szekeres, A. Ophiobolin A from Bipolaris oryzae perturbs motility and membrane integrities of porcine sperm and induces cell death on mammalian somatic cell lines. Toxins 2014, 6, 2857-2871. [CrossRef]

53. Castagnoli, E.; Salo, J.; Toivonen, M.S.; Marik, T.; Mikkola, R.; Kredics, L.; Vicente-Carrillo, A.; Nagy, S.; Andersson, M.T.; Andersson, M.A.; et al. An Evaluation of Boar Spermatozoa as a Biosensor for the Detection of Sublethal and Lethal Toxicity. Toxins 2018, 10, 463. [CrossRef] [PubMed]

54. Miller, J.D.; McMullin, D.R. Fungal secondary metabolites as harmful indoor air contaminants: 10 years on. Appl. Microbiol. Biotechnol. 2014, 98, 9953-9966. [CrossRef] [PubMed]

55. Straus, D.C. Molds, mycotoxins, and sick building syndrome. Toxicol. Ind. Health 2009, 25, 617-635. [CrossRef] [PubMed]

56. Dong, T.; Zhang, Y.; Jia, S.; Shang, H.; Fang, W.; Chen, D.; Fang, M. Human Indoor Exposome of Chemicals in Dust and Risk Prioritization Using EPA's ToxCast Database. Environ. Sci. Technol. 2019, 53, 7045-7054. [CrossRef] [PubMed]

57. Zhang, J.; Hsieh, J.H.; Zhu, H. Profiling animal toxicants by automatically mining public bioassay data: A big data approach for computational toxicology. PLoS ONE 2014, 9, e99863. [CrossRef]

58. Mikkola, R.; Andersson, M.A.; Grigoriev, P.; Teplova, V.V.; Saris, N.E.; Rainey, F.A.; Salkinoja-Salonen, M.S. Bacillus amyloliquefaciens strains isolated from moisture-damaged buildings produced surfactin and a substance toxic to mammalian cells. Arch. Microbiol. 2004, 181, 314-323.

59. Pieckova, E.; Wilkins, K. Airway toxicity of house dust and its fungal composition. Ann. Agric. Environ. Med. 2004, 11, 67-73. 
60. Holme, J.A.; Øya, E.; Afanou, A.K.J.; Øvrevik, J.; Eduard, W. Characterization and pro-inflammatory potential of indoor mold particles. Indoor Air 2020, 30, 662-681. [CrossRef] [PubMed]

61. Täubel, M.; Karvonen, A.M.; Reponen, T.; Hyvärinen, A.; Vesper, S.; Pekkanen, J. Application of the Environmental Relative Moldiness Index in Finland. Appl. Environ. Microbiol. 2015, 82, 578-584. [CrossRef] [PubMed]

62. Andersen, B.; Frisvad, J.C.; Dunn, R.R.; Thrane, U. A Pilot Study on Baseline Fungi and Moisture Indicator Fungi in Danish Homes. J. Fungi 2021, 7, 71. [CrossRef]

63. Vornanen-Winqvist, C.; Järvi, K.; Andersson, M.A.; Duchaine, C.; Létourneau, V.; Kedves, O.; Kredics, L.; Mikkola, R.; Kurnitski, J.; Salonen, H. Exposure to indoor air contaminants in school buildings with and without reported indoor air quality problems. Environ. Int. 2020, 141, 105781. [CrossRef]

64. Andersson, M.A.; Mikkola, R.; Helin, J.; Andersson, M.C.; Salkinoja-Salonen, M. A novel sensitive bioassay for detection of Bacillus cereus emetic toxin and related depsipeptide ionophores. Appl. Environ. Microbiol. 1998, 64, 1338-1343. [CrossRef]

65. Hoornstra, D.; Andersson, M.A.; Mikkola, R.; Salkinoja-Salonen, M.S. A new method for in vitro detection of microbially produced mitochondrial toxins. Toxicol. Vitr. 2003, 17, 745-751. [CrossRef]

66. Vicente-Carrillo, A.; Edebert, I.; Garside, H.; Cotgreave, I.; Rigler, R.; Loitto, V.; Magnusson, K.E.; Rodríguez-Martínez, H. Boar spermatozoa successfully predict mitochondrial modes of toxicity: Implications for drug toxicity testing and the 3R principles. Toxicol. Vitr. 2015, 29, 582-591. [CrossRef]

67. Teplova, V.V.; Belosludtsev, K.N.; Kruglov, A.G. Mechanism of triclosan toxicity: Mitochondrial dysfunction including complex II inhibition, superoxide release and uncoupling of oxidative phosphorylation. Toxicol. Lett 2017, 275, 108-117. [CrossRef]

68. Dreier, D.A.; Mello, D.F.; Meyer, J.N.; Martyniuk, C.J. Linking Mitochondrial Dysfunction to Organismal and Population Health in the Context of Environmental Pollutants: Progress and Considerations for Mitochondrial Adverse Outcome Pathways. Environ. Toxicol. Chem. 2019, 38, 1625-1634. [CrossRef] [PubMed]

69. Daiber, A.; Kuntic, M.; Hahad, O.; Delogu, L.G.; Rohrbach, S.; Di Lisa, F.; Schulz, R.; Münzel, T. Effects of air pollution particles (ultrafine and fine particulate matter) on mitochondrial function and oxidative stress-Implications for cardiovascular and neurodegenerative diseases. Arch. Biochem. Biophys. 2020, 696, 108662. [CrossRef]

70. Li, N.; Sioutas, C.; Cho, A.; Schmitz, D.; Misra, C.; Sempf, J.; Wang, M.; Oberley, T.; Froines, J.; Nel, A. Ultrafine particulate pollutants induce oxidative stress and mitochondrial damage. Environ. Health Perspect. 2003, 111, 455-460. [CrossRef]

71. Meyer, J.N.; Leung, M.C.; Rooney, J.P.; Sendoel, A.; Hengartner, M.O.; Kisby, G.E.; Bess, A.S. Mitochondria as a target of environmental toxicants. Toxicol. Sci. 2013, 134, 1-17. [CrossRef]

72. Zolkipli-Cunningham, Z.; Falk, M.J. Clinical effects of chemical exposures on mitochondrial function. Toxicology 2017, 391, 90-99. [CrossRef] [PubMed]

73. Nunnari, J.; Suomalainen, A. Mitochondria: In sickness and in health. Cell 2012, 148, 1145-1159. [CrossRef] [PubMed]

74. Mottis, A.; Herzig, S.; Auwerx, J. Mitocellular communication: Shaping health and disease. Science 2019, 366, 827-832. [CrossRef] [PubMed]

75. Moro, L. Mitochondria at the Crossroads of Physiology and Pathology. J. Clin. Med. 2020, 9, 1971. [CrossRef]

76. West, A.P. Mitochondrial dysfunction as a trigger of innate immune responses and inflammation. Toxicology 2017, 391, 54-63. [CrossRef] [PubMed]

77. Cloonan, S.M.; Kim, K.; Esteves, P.; Trian, T.; Barnes, P.J. Mitochondrial dysfunction in lung ageing and disease. Eur. Respir. Rev. 2020, 29, 200165. [CrossRef]

78. Wiegman, C.H.; Michaeloudes, C.; Haji, G.; Narang, P.; Clarke, C.J.; Russell, K.E.; Bao, W.; Pavlidis, S.; Barnes, P.J.; Kanerva, J.; et al. COPDMAP Oxidative stress-induced mitochondrial dysfunction drives inflammation and airway smooth muscle remodeling in patients with chronic obstructive pulmonary disease. J. Allergy Clin. Immunol. 2015, 136, 769-780. [CrossRef] [PubMed]

79. Gao, J.; Wang, L.; Liu, J.; Xie, F.; Su, B.; Wang, X. Abnormalities of Mitochondrial Dynamics in Neurodegenerative Diseases. Antioxidants 2017, 6, 25. [CrossRef] [PubMed]

80. Caito, S.W.; Aschner, M. Mitochondrial Redox Dysfunction and Environmental Exposures. Antioxid. Redox. Signal. 2015, 23, 578-595. [CrossRef]

81. Fetterman, J.L.; Sammy, M.J.; Ballinger, S.W. Mitochondrial toxicity of tobacco smoke and air pollution. Toxicology 2017, 391, 18-33. [CrossRef]

82. Manevski, M.; Muthumalage, T.; Devadoss, D.; Sundar, I.K.; Wang, Q.; Singh, K.P.; Unwalla, H.J.; Chand, H.S.; Rahman, I. Cellular stress responses and dysfunctional Mitochondrial-cellular senescence, and therapeutics in chronic respiratory diseases. Redox. Biol. 2020, 33, 101443. [CrossRef]

83. Sundar, I.K.; Maremanda, K.P.; Rahman, I. Mitochondrial dysfunction is associated with Miro1 reduction in lung epithelial cells by cigarette smoke. Toxicol. Lett. 2019, 317, 92-101. [CrossRef]

84. Sachdeva, K.; Do, D.C.; Zhang, Y.; Hu, X.; Chen, J.; Gao, P. Environmental Exposures and Asthma Development: Autophagy, Mitophagy, and Cellular Senescence. Front. Immunol. 2019, 10, 2787. [CrossRef] [PubMed]

85. Korkalainen, M.; Täubel, M.; Naarala, J.; Kirjavainen, P.; Koistinen, A.; Hyvärinen, A.; Komulainen, H.; Viluksela, M. Synergistic proinflammatory interactions of microbial toxins and structural components characteristic to moisture-damaged buildings. Indoor Air 2017, 27, 13-23. [CrossRef] [PubMed]

86. van Horssen, J.; van Schaik, P.; Witte, M. Inflammation and mitochondrial dysfunction: A vicious circle in neurodegenerative disorders? Neurosci. Lett. 2019, 710, 132931. [CrossRef] 
87. Mazzone, S.B.; Undem, B.J. Vagal Afferent Innervation of the Airways in Health and Disease. Physiol. Rev. 2016, 96, 975-1024. [CrossRef]

88. Viana, F. Chemosensory properties of the trigeminal system. ACS Chem. Neurosci. 2011, 2, 38-50. [CrossRef]

89. Rasimus-Sahari, S.; Mikkola, R.; Andersson, M.A.; Jestoi, M.; Salkinoja-Salonen, M. Streptomyces strains producing mitochondriotoxic antimycin A found in cereal grains. Int. J. Food. Microbiol. 2016, 218, 78-85. [CrossRef]

90. Stanford, K.R.; Hadley, S.H.; Barannikov, I.; Ajmo, J.M.; Bahia, P.K.; Taylor-Clark, T.E. Antimycin A-induced mitochondrial dysfunction activates vagal sensory neurons via ROS-dependent activation of TRPA1 and ROS-independent activation of TRPV1. Brain Res. 2019, 1715, 94-105. [CrossRef] [PubMed]

91. Bahia, P.K.; Hadley, S.H.; Barannikov, I.; Sowells, I.; Kim, S.H.; Taylor-Clark, T.E. Antimycin A increases bronchopulmonary C-fiber excitability via protein kinase C alpha. Respir. Physiol. Neurobiol. 2020, 278, 103446. [CrossRef]

92. Ruan, T.; Lin, Y.J.; Hsu, T.H.; Lu, S.H.; Jow, G.M.; Kou, Y.R. Sensitization by pulmonary reactive oxygen species of rat vagal lung C-fibers: The roles of the TRPV1, TRPA1, and P2X receptors. PLoS ONE 2014, 9, e91763. [CrossRef]

93. Lehmann, R.; Schöbel, N.; Hatt, H.; van Thriel, C. The involvement of TRP channels in sensory irritation: A mechanistic approach toward a better understanding of the biological effects of local irritants. Arch. Toxicol. 2016, 90, 1399-1413. [CrossRef]

94. Silverman, H.A.; Chen, A.; Kravatz, N.L.; Chavan, S.S.; Chang, E.H. Involvement of Neural Transient Receptor Potential Channels in Peripheral Inflammation. Front. Immunol. 2020, 11, 590261. [CrossRef] [PubMed]

95. Green, D.P.; Limjunyawong, N.; Gour, N.; Pundir, P.; Dong, X. A Mast-Cell-Specific Receptor Mediates Neurogenic Inflammation and Pain. Neuron 2019, 101, 412-420.e3. [CrossRef] [PubMed]

96. Kabata, H.; Artis, D. Neuro-immune crosstalk and allergic inflammation. J. Clin. Investig. 2019, 129, 1475-1482. [CrossRef]

97. Thapaliya, M.; Chompunud Na Ayudhya, C.; Amponnawarat, A.; Roy, S.; Ali, H. Mast Cell-Specific MRGPRX2: A Key Modulator of Neuro-Immune Interaction in Allergic Diseases. Curr. Allergy Asthma Rep. 2021, 21, 1-11. [CrossRef]

98. Shouman, K.; Benarroch, E.E. Peripheral neuroimmune interactions: Selected review and some clinical implications. Clin. Auton. Res. 2021, 31, 477-489. [CrossRef] [PubMed]

99. Bessac, B.F.; Jordt, S.E. Breathtaking TRP channels: TRPA1 and TRPV1 in airway chemosensation and reflex control. Physiology 2008, 23, 360-370. [CrossRef]

100. Tillie-Leblond, I.; Montani, D.; Crestani, B.; de Blic, J.; Humbert, M.; Tunon-de-Lara, M.; Magnan, A.; Roche, N.; Ostinelli, J.; Chanez, P. Relation between inflammation and symptoms in asthma. Allergy 2009, 64, 354-367. [CrossRef] [PubMed]

101. Jaramillo, A.M.; Azzegagh, Z.; Tuvim, M.J.; Dickey, B.F. Airway Mucin Secretion. Ann. Am. Thorac. Soc. 2018, 15, S164-S170. [CrossRef] [PubMed]

102. Taylor-Clark, T.E. Role of reactive oxygen species and TRP channels in the cough reflex. Cell Calcium 2016, 60, 155-162. [CrossRef]

103. Taylor-Clark, T.E.; Undem, B.J. Sensing pulmonary oxidative stress by lung vagal afferents. Respir. Physiol. Neurobiol. 2011, 178, 406-413. [CrossRef] [PubMed]

104. Oetjen, L.K.; Mack, M.R.; Feng, J.; Whelan, T.M.; Niu, H.; Guo, C.J.; Chen, S.; Trier, A.M.; Xu, A.Z.; Tripathi, S.V.; et al. Sensory Neurons Co-opt Classical Immune Signaling Pathways to Mediate Chronic Itch. Cell 2017, 171, 217-228.e13. [CrossRef]

105. Diver, S.; Russell, R.J.; Brightling, C.E. Cough and Eosinophilia. J. Allergy. Clin. Immunol. Pract. 2019, 7, 1740-1747. [CrossRef] [PubMed]

106. Chung, K.F. Approach to chronic cough: The neuropathic basis for cough hypersensitivity syndrome. J. Thorac. Dis. 2014, 6, S699-S707.

107. Pecova, T.; Kocan, I.; Vysehradsky, R.; Pecova, R. Itch and Cough-Similar Role of Sensory Nerves in Their Pathogenesis. Physiol. Res. 2020, 69, S43-S54. [CrossRef]

108. Smeitink, J.; Koene, S.; Beyrath, J.; Saris, C.; Turnbull, D.; Janssen, M. Mitochondrial Migraine: Disentangling the angiopathy paradigm in m.3243A $>$ G patients. JIMD Rep. 2019, 46, 52-62. [PubMed]

109. Conti, P.; D’Ovidio, C.; Conti, C.; Gallenga, C.E.; Lauritano, D.; Caraffa, A.; Kritas, S.K.; Ronconi, G. Progression in migraine: Role of mast cells and pro-inflammatory and anti-inflammatory cytokines. Eur. J. Pharmacol. 2019, 844, 87-94. [CrossRef] [PubMed]

110. Gross, E.C.; Lisicki, M.; Fischer, D.; Sándor, P.S.; Schoenen, J. The metabolic face of migraine-from pathophysiology to treatment. Nat. Rev. Neurol. 2019, 15, 627-643. [CrossRef] [PubMed]

111. Dux, M.; Rosta, J.; Messlinger, K. TRP Channels in the Focus of Trigeminal Nociceptor Sensitization Contributing to Primary Headaches. Int. J. Mol. Sci. 2020, 21, 342. [CrossRef] [PubMed]

112. Renner, B.; Mueller, C.A.; Shephard, A. Environmental and non-infectious factors in the aetiology of pharyngitis (sore throat). Inflamm. Res. 2012, 61, 1041-1052. [CrossRef]

113. Sundar, K.M.; Stark, A.C.; Hu, N.; Barkmeier-Kraemer, J. Is laryngeal hypersensitivity the basis of unexplained or refractory chronic cough? ERJ Open Res. 2021, 7, 00793-02020. [CrossRef]

114. Wang, W.; Xian, M.; Xie, Y.; Zheng, J.; Li, J. Aggravation of airway inflammation and hyper-responsiveness following nasal challenge with Dermatophagoides pteronyssinus in perennial allergic rhinitis without symptoms of asthma. Allergy 2016, 71, 378-386. [CrossRef] [PubMed]

115. Eifan, A.O.; Durham, S.R. Pathogenesis of rhinitis. Clin. Exp. Allergy 2016, 46, 1139-1151. [CrossRef] [PubMed]

116. Yang, Z.; Liang, C.; Wang, T.; Zou, Q.; Zhou, M.; Cheng, Y.; Peng, H.; Ji, Z.; Deng, Y.; Liao, J.; et al. NLRP3 inflammasome activation promotes the development of allergic rhinitis via epithelium pyroptosis. Biochem. Biophys. Res. Commun. 2020, 522, 61-67. [CrossRef] [PubMed] 
117. Järvenpää, P.; Arkkila, P.; Aaltonen, L.M. Globus pharyngeus: A review of etiology, diagnostics, and treatment. Eur. Arch. Otorhinolaryngol. 2018, 275, 1945-1953. [CrossRef]

118. Beuerman, R.W.; Stern, M.E. Neurogenic inflammation: A first line of defense for the ocular surface. Ocul. Surf. 2005, 3, S203-S206. [CrossRef]

119. Ryder, E.C.; Benson, S. Conjunctivitis; StatPearls Publishing LLC: Treasure Island, FL, USA, 2021; pp. 1-4.

120. Ranjbaran, Z.; Keefer, L.; Stepanski, E.; Farhadi, A.; Keshavarzian, A. The relevance of sleep abnormalities to chronic inflammatory conditions. Inflamm. Res. 2007, 56, 51-57. [CrossRef] [PubMed]

121. Besedovsky, L.; Lange, T.; Haack, M. The Sleep-Immune Crosstalk in Health and Disease. Physiol. Rev. 2019, 99, 1325-1380. [CrossRef] [PubMed]

122. Brunetti, V.; Della Marca, G.; Servidei, S.; Primiano, G. Sleep Disorders in Mitochondrial Diseases. Curr. Neurol. Neurosci. Rep. 2021, 21, 1-9. [CrossRef] [PubMed]

123. Gohy, S.T.; Hupin, C.; Pilette, C.; Ladjemi, M.Z. Chronic inflammatory airway diseases: The central role of the epithelium revisited. Clin. Exp. Allergy 2016, 46, 529-542. [CrossRef]

124. Pieckova, E.; Jesenska, Z. Molds on house walls and the effect of their chloroform-extractable metabolites on the respiratory cilia movement of one-day-old chicks in vitro. Folia Microbiol. 1998, 43, 672-678. [CrossRef] [PubMed]

125. Pieckova, E.; Kunova, Z. Indoor fungi and their ciliostatic metabolites. Ann. Agric. Environ. Med. 2002, 9, 59-63. [PubMed]

126. Mack, S.M.; Madl, A.K.; Pinkerton, K.E. Respiratory Health Effects of Exposure to Ambient Particulate Matter and Bioaerosols. Compr. Physiol. 2019, 10, 1-20.

127. Lochhead, J.J.; Thorne, R.G. Intranasal delivery of biologics to the central nervous system. Adv. Drug Deliv. Rev. 2012, 64, 614-628. [CrossRef] [PubMed]

128. Rojo, A.I.; Montero, C.; Salazar, M.; Close, R.M.; Fernández-Ruiz, J.; Sánchez-González, M.A.; de Sagarra, M.R.; Jackson-Lewis, V.; Cavada, C.; Cuadrado, A. Persistent penetration of MPTP through the nasal route induces Parkinson's disease in mice. Eur. J. Neurosci. 2006, 24, 1874-1884. [CrossRef] [PubMed]

129. Miller, M.R.; Raftis, J.B.; Langrish, J.P.; McLean, S.G.; Samutrtai, P.; Connell, S.P.; Wilson, S.; Vesey, A.T.; Fokkens, P.H.B.; Boere, A.J.F.; et al. Inhaled Nanoparticles Accumulate at Sites of Vascular Disease. ACS Nano 2017, 11, 4542-4552. [CrossRef] [PubMed]

130. Baral, P.; Udit, S.; Chiu, I.M. Pain and immunity: Implications for host defence. Nat. Rev. Immunol. 2019, 19, 433-447. [CrossRef]

131. Sotnichenko, A.; Pantsov, E.; Shinkarev, D.; Okhanov, V. Hydrophobized Reversed-Phase Adsorbent for Protection of Dairy Cattle against Lipophilic Toxins from Diet. Efficiensy in Vitro and in Vivo. Toxins 2019, 11, 256. [CrossRef] 